\title{
Research on Sustainable Development of Tourism Industry
}

\author{
Ran Li \\ Xi'an University \\ Xi'an, China 710065 \\ Xinling Feng \\ Xi'an University \\ Xi'an, China 710065
}

\author{
$\mathrm{Xin} \mathrm{Su}$ \\ Xi'an University \\ Xi'an, China 710065 \\ Aimei Yang \\ Xi'an University \\ Xi'an, China 710065
}

\begin{abstract}
This paper introduces the concept of tourism industry and the development status of China's tourism industry. It expounds some problems existing in the development of China's tourism industry, and puts forward some ways to realize the sustainable development of this industry according to these problems and the characteristics of sustainable development of tourism.
\end{abstract}

Keywords-tourism industry; economy; sustainable development

\section{INTRODUCTION}

With the improvement and satisfaction of material living conditions, people pay more and more attention to the relaxation and development of their body and mind, and tourism has thus become the main leisure way for people. In recent years, the fast-growing tourism industry has become an indispensable part in the development of China's economy. Therefore, it is necessary to clarify the impact of tourism industry on the economy and find out the way of its sustainable development [1] [2] [3].

\section{OVERVIEW OF TOURISM INDUSTRY DEVELOPMENT}

Tourism industry is an industry that provides tourists with tour services based on tourism resources and relying on relevant tourism equipment. It is also known as green industry and natural trade. Tourism, tourism transport and tourism service represented by hotels, are the three pillars of tourism. Tourism is poised to overtake traditional manufacturing and heavy industry and become a pillar of the world economy, according to the world tourism organization. In China, tourism industry has become an indispensable part of the national economy and plays an important role in the market economy. China's tourism industry started late but developed rapidly, having an irreplaceable position and role in the national economy. Before the reform and opening up, China's tourism industry model was very simple, mainly inbound tourism receiving foreign tourists, with immature domestic tourism market and very low number of domestic tourists and consumption level. It wasn't until the reform and opening up that China's tourism really got off the ground.
The tourism industry attributes are constantly upgrading in the transformation, the cultivation of industrial system is increasingly diversified, and the development of tourism market is gradually deepened in an ordered way [4].

\section{THE IMPACT OF TOURISM INDUSTRY ON ECONOMY}

\section{A. Positive Impact of Tourism on Economy}

1) Its impact on social output value and national income: As a service industry, tourism stimulates the consumption scale and increase people's consumption desire when providing services for them, which will increase the social output value. It can increase national income and make the wealth flow to the bottom of society. When the tourism industry provides services, consumers pay money while service providers pay services. The exchange of services for wealth will speed up the flow of social wealth and accumulate wealth downward so as to help to reduce the gap between the rich and the poor. In some places with good environmental resources and less developed industry and commerce, the tourism industry is of great help to local economy and can effectively drive its development [5].

2) Its impact on employment: There are many types of tourism employment, which can attract workers of different ability levels so as to solve the employment problem of a large number of labor forces. Facts have proved that the role of tourism in increasing the income of the masses is not to be ignored. With the characteristics of low investment, high return, and short period, etc., it is the choice of many scenic areas. Due to the seasonality of many tourism resources and scenic spots, tourists go to sightseeing in specific seasons, so the requirements of tourism practitioners in these places are also volatile; in addition, there are various types of tourism employment, and there are many temporary and part-time workers in the industry. Tourism is a service industry based on tourism consumption. It is closely related to other industries. The development of tourism promotes 
the employment of other industries and thus makes a great contribution to society.

3) Its impact on other industries: According to the survey of the WTO, the impact ratio of tourism industry and other related industries is as high as one to seven, which is incomparable among industries. In addition, the flow of tourism consumers between different regions promotes the development of the local transportation industry, greatly increasing the income of the transportation industry and bringing a considerable income to the local finance. At the same time, the large increase of tourists has also promoted the development of local catering and accommodation industries. This in turn requires the improvement of the quantity and quality of hotel accommodation facilities, which requires the better development of the accommodation industry and the construction industry. Like the construction industry, tourism also indirectly promotes the development of industrial production. Many cities have grown up on tourism, which is especially true of the Midwest cities. Driven by tourism, urban construction is also carried out in these cities, which also requires the construction of a high-quality urban facility and thus improves the level of local development.

4) Its impact on the balance of international payments: The tourism industry can balance the balance of payments, which is especially obvious in developing countries. The tourism industry in many developing countries is designed to receive inbound tourism, which acts as a medium for exchange of foreign exchange. Most developing countries in the world encourage inbound tourism. Due to the relatively backward economy of these countries, their residents seldom travel abroad, so the tourism foreign exchange income is more than the tourism foreign exchange expenditure, thereby balancing the foreign exchange deficit caused by other industries of these countries. In addition, tourism can also help to recoup domestic funds, which are mainly collected by guiding domestic people to spend money on tourism.

\section{B. Negative Impact of Tourism on Economy}

1) Excessive development of tourism resources: In order to develop the local tourism industry, many regions do not hesitate to destroy local tourism resources and overload tourists. While developing the economy, they pay the price of environmental destruction. Some nature reserves receive a large number of tourists for economic benefits, which is beyond the capacity of the scenic area. At the same time, a large number of human activities interfere with the local animal and plant activities, and even threaten their habitat, pushing them to the edge of extinction and thus causing serious damage to the local ecosystem. Tourism industry brings high economic benefits, along with a scarred and battered ecological environment. In order to restore the ecological environment, local governments have to spend a huge amount of money to deal with environmental problems.
Therefore, the over-exploitation of tourism resources will not only bring disasters to the environment, but also bring local economy into difficulties [6].

2) Inflation: The tourism industry will also lead to inflation and rising house prices in tourist destinations. The influx of a large number of high foreign consumers will push up the price of commodities including housing prices in tourist destinations, while the increase of local people's incomes cannot keep pace with the rate of inflation, which will seriously damage the interests of local people. This is the case in many of China's touristy cities. The rising prices and cost of living have brought great trouble to the local ordinary people.

\section{PROBLEMS EXISTING IN THE DEVELOPMENT OF CHINA'S TOURISM INDUSTRY}

\section{A. Hypernormal Development of Tourism}

The hypernormal development of China's tourism industry is determined by the national conditions. In order to keep the balance of international payments, they can only rely on the development of inbound tourism to make up for the less foreign exchange earned in other industries. The hypernormal development mode makes China's tourism industry develop rapidly and the popularity of China's tourism industry increases rapidly internationally. However, this development model also has a major disadvantage. That is, since the tourism centers in inbound tourism, it cannot meet the needs of domestic consumers. Especially with the growth of China's economy, people's tourist demand is increasing, which leads to the underdevelopment of the domestic tourism market.

\section{B. Uneven Development Among Regions}

There is a serious imbalance in regional development in China's Tourism, mainly the imbalance between the East and the Midwest. With a strong economic strength, the eastern coastal region is endowed with abundant modern urban tourism resources while developing the original natural resources, which is of great attraction to tourists at home and abroad, and also leads to the main concentration of Chinese tourists in the east. It developed economy also contributes to convenient transportation. By contrast, although there are many natural resources in the Midwest, they cannot be developed effectively due to the lack of convenient transportation network. What's more, the eastern region has a high degree of reform, intense economic and cultural exchanges with foreign countries, and thus has the economic advantages of tourism.

\section{Imperfect Tourism Laws and Regulations}

Laws and regulations related to China's tourism industry are not yet perfect. At the national level, there is no relevant legislation and regulations, and plan for the future development of the tourism industry. At the local level, there are no local laws and regulations, detailed regulations on how to develop and plan tourist attractions, and clear regulations on violations in tourism development. Due to the 
lack of legal constraints, many developers receive overloaded tourists at the expense of environmental damage in order to make more money. Some of them even conduct private deals when operating tourism projects, disturbing the market order and damaging the rights and interests of consumers.

\section{WAYS TO REALIZE THE SUSTAINABLE DEVELOPMENT OF CHINA'S TOURISM INDUSTRY}

\section{A. Cultivating High-quality Tourism Professionals}

China's tourism industry is in urgent need of professional talents, including talents in planning, operation and maintenance. Tourism industry is an industry with high professional requirements. In order to realize the sustainable development of tourism industry, it is necessary to strengthen efforts to cultivate more professionals. Specific methods include: first, professional training should be conducted for those who are already working in the tourism industry to improve their professional quality and views on the tourism industry in the new era; second, the employment rate of college students majoring in tourism in the industry should be improved, which can not only alleviate the employment pressure but also effectively use human resources since there are many graduates majoring in tourism who are not engaged in tourism-related jobs; third, the state should introduce the corresponding tourism market standards to improve the market access threshold because the current tourism market is a mess, and anyone can become a tourism staff, which is very adverse to the healthy and sustainable development of tourism. Therefore, training more tourism professionals is the right direction for the sustainable development of China's tourism industry.

\section{B. Establishing and Improving Relevant Laws and Regulations}

It is urgent to establish and improve relevant laws and regulations. At the national level, it is necessary to speed up the promulgation of national laws and regulations; make a long-term plan for China's future tourism development; take the sustainable development of tourism as a national strategy; guide local legislation; and elaborate relevant eco-tourism development, environmental protection measures and tourism market establishment. Local governments should introduce some practical and detailed local laws and policies with the national plan as the blueprint according to local conditions, regulate the local tourism market to clarify the supervision system of the tourism market, severely punish the units and individuals that destroy the environment and disrupt the normal market order, and guide the development of the tourism industry in a correct and benign way.

\section{Formulating Scientific and Reasonable Tourism Planning}

Tourism planning is the core of the whole tourism project. Throughout the development of tourism projects, from the initial development planning to the later operation planning and later protection planning, planning is of extraordinary significance. Tourism planning must be made based on the sustainable development center, proceed from the overall tourism project to work out a reasonable and scientific tourism development method. In addition, the state should make an overall plan for the national tourism resources, increase the development of the tourism industry in the western region to break the unbalanced development between the original regions and develop the national tourism resources in a scientific and rational way. It is necessary to make overall planning of tourism resources throughout the country according to the needs of national development. In this way, the lopsided development among regions can be balanced, the tourism resources in the central and western regions can be fully developed, and the wasteful development of different regions can be avoided, which plays an important role in the sustainable development of the national tourism industry.

\section{Actively Developing Ecotourism}

Ecotourism refers to coordinating the relationship between tourism development and ecological protection when developing tourism projects. It aims to protect the environment directly and is one of the best ways to achieve sustainable development of tourism industry. There are still many deficiencies in the development of ecotourism in China, which mainly lies in the lack of awareness of developers and tourists. It requires developers to work together with tourists to better develop ecotourism. Developers should plan tourism resources in a scientific and reasonable way, instead of overdeveloping or overloading, and try to protect the diversity of local ecological environment when developing. Tourists are also a part of ecotourism as the direct consumers of tourism resources. Some tourists throw garbage and hurt animals at will when traveling, which are not in line with the development of ecotourism. Ecotourism requires tourists to protect the environment and not to harm animals and plants willfully. Active development of ecotourism will be the trend of China's tourism development, which requires the whole society to work together to participate in ecotourism.

\section{CONCLUSION}

The ultimate goal of sustainable development of tourism is to meet the needs of tourists and local economic development through scientific and rational planning and development of tourism resources, and improve the living standard of local residents as much as possible; at the same time, to protect the vitality of tourism resources and ensure that they are not over-developed, so as to finally achieve the coordinated development of industrial growth, natural resources and ecological environment.

\section{REFERENCES}

[1] Li Changrong. Sustainable Development of Ecotourism [M]. China Forestry Publishing House, 2004. (in Chinese)

[2] Zhang Guangrui. Study on the Sustainable Development of Tourism Scenic Spots [M]. China Travel \& Tourism Press, 2012. (in Chinese)

[3] Hu Fen. On the Sustainable Ecological Development of Tourism Industry [M]. China Environmental Science Press, 2009. (in Chinese) 
[4] Liu Chunji, Feng Xuegang, Gao Jing, et al. Changes in the Structure of the Tourism Industry and Their Effect on the Growth of the Tourism Economy in China [J]. Tourism Tribune, 2014, 29(8): 37-49. (in Chinese)

[5] Wu Jin. Analysis of the relationship between tourism industry upgrading and tourism economic growth [J]. Journal of Changsha Social Work College, 2014(1): 82-83. (in Chinese)

[6] Wei Xiaonan. Research on the impact of changes in tourism industry structure on China's tourism economic growth [J]. Journal of Jilin Radio and TV University, 2016(7): 31-32. (in Chinese) 